\title{
THE SISYPHEAN MYTH, NEGATIVE CAPABILITY AND SOCIETAL RELEVANCE
}

\author{
Chike Okoye* \\ http://dx.doi.org/10.4314/og.v11i 1.6
}

\begin{abstract}
Different forms of literature over the years have expressed mankind's views, thoughts, notions, beliefs, and inclinations. The feelings of futility, negativity, absurdism, nihilism expressed in the myth of Sisyphus is just one of the numerous representations that literature can offer. But not all literary expressions are posers of questions and problems. Certain concepts such as Keats' Negative Capability suggest solutions to Camus' Sisyphean problem and its ilk. This paper explores this problem-solution relationship and finds complementarity and possibility feasible.
\end{abstract}

\section{Introduction}

There has been a relationship, an age-long one, between literary concepts and life and existence in general. This could be largely symbiotic in a two-directional manner; that is, literary concepts could affect and enhance behaviour or on the other hand, observations of life might generate a concept illustrative of the said observation. Generally, whichever is the case, there is always a noticeable inter-relatedness between life and literature; and this consanguinity essentially underscores the relevance of literature - a relevance which is partially based on its simulated model of actuality. The firm familiarity it offers forearms one in readiness to brace the vicissitudes of real life.

In the light of the above, myths could be discussed in this context as one of those simulated models that prepare us and give us a second handle on reality a la Achebe; albeit a more malleable and friendly one. Myths and mythology are as old as mankind. They constitute those ancient, traditional and unfounded stories (in most cases regarded as historical) which help to explain the worldview of a people, or elucidate a major conventional trend. In chapter four of 
Albert Camus' treatise on absurdism, The Myth of Sisyphus, entitled 'The Myth of Sisyphus', he retells the Greek legend of Sisyphus; a legend that effectively accentuates for pessimists, the general futility and meaninglessness of life - a sort of nihilistic agon. The story is that Sisyphus defied the gods and incarcerated Death in chains so that no human needed to die. When Death was finally freed and Sisyphus' own death came, he plotted a deceit that facilitated his escape from the underworld. He was later captured and the gods decided to punish him thus: that for all eternity, he would have to push a rock up a mountain; and on the top it would roll down and he would start afresh.

This never-ending and apparently purposeless toil could be convincingly seen as a metaphor for the drab routine of our everyday occupation(s) in this industrialised age; especially with factory, office, and other numerous white-collar jobs. On a broader scale, it portrays the generally negative and bleakly pessimistic slant mankind and life has assumed in which purpose, value of achievement, and our earthly existences are questioned. In all, two major concepts are readily discernible: negativity and uncertainty.

\section{Allied Literatures}

These concepts in literature are in line with the realm of absurdist theatre akin to what has been discussed above. The concepts have notable proponents in writers such as Strindberg, O'Neil, Beckett, etc. These writers have tried to showcase the futility and meaninglessness of existence; where suffering and bleak prospects are the only linings in the smog-filled horizon. Beckett's classic Waiting for Godot features two major characters, Vladimir (Didi) and Estragon (Gogo) who are tramps alongside Pozzo and Lucky; the classic duo whose reversal of fortunes happens to be the only change in the entire play. In full-fledged absurdist fashion, nothing 'happens' in the play as the tramps wait continuously for a character, Godot, who never appears. While in the wait, nothing significant happens except idle talk and banter and a pervading psychological, mental and physical inertia of the apparent futility of their wait. Just 
like the Sisyphean theme, it is clear that negativity pervades the realms of man's existence.

In poetry, Thomas Hardy's pessimism comes to the fore; taking Nature to task. The whole idea of creation, existence and purpose in life is in scarcely-veiled scathing sarcasm, questioned; questioned in a manner that suggests abandonment and neglect of the species by 'whomever' or 'whatever force' responsible for our animation. The poem, aptly titled 'Nature's Questioning' is Hardy's own accusation and indictment of Nature for a perceived purposeless life fraught with neglect and lack of direction. He applies the synecdoche of 'field, flock and lonely tree', for earth's flora and fauna and presents them as murmuring barely audible protests ('...stirs, in lippings mere...'): 'We wonder, ever wonder, why/ we find us here!'. The protests do not end there. The living inhabitants of earth decide to musingly toy with theories of a great but brainless creator that is intrinsically callous. Hear them:

\author{
Has some Vast Imbecility, \\ Mighty to build and blend, \\ But impotent to tend, \\ Framed us in jest, and left us \\ now to hazardry?
}

The undertones and insinuations of neglect and helplessness and a hint of mischief from the 'Creator' are not missing in the above.

Nevertheless, the questions do not end there; they continue:

Or come we of an Automaton Unconscious of our pains?... 
Or are we live remains

Of Godhead dying downwards,

brain and eye now gone?

Or is it that some high Plan

betides,

As yet not understood,...?

From the above, the questions remain: Does our creator not know of our sufferings? Or are we components of a Godhead that in progressive decay and deterioration has lost intellect and foresight? Or is there really a plan for and about us that is yet to be understood? The fundamental common denominator of all of Hardy's musings remains the meaningless suffering and absurdity of existence. Meanwhile, the special and forceful poignancy of poetry lends weight in the treatment of Hardy's views in this paper.

On a less absurdist but all the same aptly realistic perspective, we bring in Wilfred Owen's views in his poem 'Dulce et Decorum Est' as he questions profoundly one of the contrived 'values' of a socalled meaningful existence in life - that of valour and sacrifice in battle. The poem's title, 'Dulce et Decorum Est' means 'it is sweet and right'; this being one half of a saying meant to create value for a soldier's sacrifice of his life in the battlefield. A soldier himself, Owen ends up painting a horrific picture of the harsh, gory, and horrid realities of war aimed at debunking the glorious myth of 'dying sweetly for one's country'. Hear him:

If in some smothering dreams you too could pace

Behind the wagon that we flung him in,

And watch the white eyes writhing in face, 
His hanging face, like a devil's sick of sin;

If you could hear, at every jolt, the blood

Come gargling from the froth-corrupted lungs,

Obscene as cancer,...

My friend, you would not tell with such high

zest

To children ardent for some desperate glory,

The old Lie; Dulce et Decorum est

Pro patria mori.

In the above, the poet paints one of the most horrifying spectacles of the First World War: a scene of victims of a successful gas-attack, and uses it as a repulsive backdrop to debunk the idealistic lie: dulce et decorum est pro patria mori (it is sweet and right to die for your country). The inclusion of Owen's misgivings about conventional 'values' which are in reality meaningless, act like a sort of illustrative silhouette on the central discourse of absurdism, negativity, and the general purposelessness and meaninglessness of life that has been the thrust of this paper.

So far, that most endeavours of mankind as have been exemplified starting with Camus' Sisyphean myth are basically absurd and purposeless does not necessarily mean that solutions have not been sought after. Contemplations on issues of absurdism, scepticism, and dubiety are not restricted to Camus, Hardy and Owen; they are just a minute fraction of a multitude of like-minds. Other thinkers and writers too have mused on similar concepts albeit on varied and interesting perspectives. The nineteenth century Romantic poet, John Keats is one of such examples. 


\section{Negative Capability: Relevance}

Keats made an interesting observation and propounded the theory of 'Negative Capability' in which he described the human capacity for accepting uncertainties and the unresolved. In a letter to his brothers dated Sunday $21^{\text {st }}$ December, 1817 , he says

I had not a dispute but a disquisition with Dilke, on various

subjects... what quality went to form a Man of Achievement

especially in literature and which Shakespeare possessed so

enormously - I mean Negatively Capability, that is when man

is capable of being in uncertainties, Mysteries, doubts with-

out any irritable reaching after fact and reason....

Keats does not end with the passive outcome of Negative Capability; i.e., the base quality of just 'being there'. He extends it to 'what quality went to form a Man of Achievement'; i.e., it is (Negative Capability) actually an ingredient in the formation of a man of genius. He sees this genius in the man, Shakespeare; and this capability enables men of genius to make the best out of ugly, drab situations by seeing beauty in the most unlikely of things and accepting problems 'without any irritable reaching after fact and reason'. His theory is somewhat based on the idea that greatness actually comes from a subsuming of self; and not a conscious reaching out in the mould of Wordsworth's 'egotistic sublime', which he had earlier muted in another letter dated $22^{\text {nd }}$ November, 1817 and said that 'men of genius' do not have 'any individuality' or 'determined character'. This notion which is essential to the basis of 
Negative Capability has been tinkered with by another great literati, T.S. Eliot. Eliot in his essay 'Tradition and the Individual Talent' opines that 'the progress of an artist is a continual self-sacrifice, a continual extinction of personality'. In an insightful and illuminating logic, it is interesting to perceive that it actually takes a great personality to accept that not everything in life can be resolved. And this belief which Keats incidentally had was highly instrumental to his development of the theory.

In knitting the conceptual strands of this treatise together, the problematic warps of absurdism, scepticism and dubiety of Camus, Hardy, Owen and their likes, join constructively, the wefts of Keats and Eliot. In situations of hopelessness, the seeds or kernels of positivity and greatness could well-nigh be nestling in potentiality, waiting to act; as long as the self is subsumed and there is no irritable reaching out for facts and solutions. The Sisyphean problem finds a solution in Negative Capability.

Changes continue to occur; especially in the world of literature. The ancient notions of tragedy and heroism as suggested and established by the classics are being modified now to suit today's society. Aristotle's and Seneca's prescriptions of noble births, tragic flaws, hubris, incests, ghosts, dead bodies, etc., as the components or requisites for tragedies and tragic heroes find a radical change when we consider Arthur Miller's Death of a Salesman - a full tragedy in its own right! But without the classic prescriptions. Again, according to Achebe, modern tragedy is no longer an almost sudden crash from grace to grass of the hero, but a gradual, continual, and debilitating process. He likens it to a bowl of wormwood which you are compelled to sip a little at a time. At this point, a change in belief is also feasible.

\section{Conclusion}

On the basis of Negative Capability, erstwhile hopeless situations, beliefs, characters, etc., could now be viewed as positive and even great. Unoka, the 'failure' of Achebe's Things Fall Apart will 
suffice as illustration. Just like the changes that are inevitable in life and convention, notions are also prone to evolution. Unoka, the never-do-well father of the novel's protagonist, Okonkwo, could be viewed less negatively using the lens of Negative Capability. Afterall, one would say he faced death happily, clutching his flute as his abominable corpse made its way to the evil forest; while his 'hero' son Okonkwo experienced a grief-laden, repugnant and scandalous end - suicide.

Finally, Keats has equipped us with a way of handling the vicissitudes of life. Based on the view that life is absurd, hopeless, pointless and purposeless, and that majority of our values are at best meaningless, Negative Capability in such situations will help us find value and retain our sanity while holding our heads above water especially in these worsening and debilitating times.

*Chike Okoye PhD, Department of English Language and Literature, Nnamdi Azikiwe University, Awka okpilimbem@gmail.com. 
Okoye: The Sisyphean myth, negative capability...

\section{References}

Achebe, Chinua. Things Fall Apart. Ibadan: Heinemann, 1958.

Applegate, James et al. Adventures in World Literature. New York: Harcourt Brace Jovanovich, 1970.

Ferguson, Margaret et al. The Norton Anthology of Poetry ( $4^{\text {th }}$ ed $)$. New York: Norton, 1996.

Gibson, James (ed). The Complete Poems of Thomas Hardy. London: Macmillan, 1976.

Rosenberg, Donna. World Mythology ( $2^{\text {nd }}$ ed). Chicago: NTC, 1994. 